\title{
Assessment of Measures for Tax Regulation of Transfer Pricing from the Standpoint of National Welfare
}

\section{Liudmila Polezharova}

PhD in Economics, Associate Professor, $\underline{\text { ORCID }}$

E-mail: LVPolezharova@fa.ru

Financial University under the Government of the Russian Federation

(Financial University), Moscow, Russia

Journal of Corporate Finance Research, Vol. 14, No. 1, pp. 80-90 (2020)

DOI: https://10.0.67.171/j.jcfr.2073-0438.14.1.2020.80-90

Received 18 February 2020 | Peer-reviewed 24 March 2020 | Accepted 27 March 2020 


\section{Assessment of Measures for Tax Regulation of Transfer Pricing from the Standpoint of National Welfare}

\section{Abstract}

This article is devoted to development of mathematical models for resolving an actual scientific challenge in the field of corporate finance. This involves substantiating taxation policies for the counter-acting tax planning of multinational companies (MNC), and then devising and articulating the appropriate international taxation scheme, as evaluated from the position of national welfare policy. Based on an analysis of existing models of international taxation, and on the peculiarities of the actual mechanism of capital movement tax regulation, new models with equilibrium postulated have been developed.

The primary mechanisms of this research involve the following considerations: (1) examination of an approach targeted at the determination of the final outcomes of international taxation from the perspective of national economies; (2) measures of tax planning on the part of MNCs, and corresponding counter-acting measures to the tax planning applied by governments, are taken as a complex.

Our results indicate that because a government uses rules of controlled transactions, in order to counter-act MNCs' tax planning, for the government the final outcome from an application of these rules may be negative. This is due to a possibility of MNCs' development in convenient and offshore jurisdictions. This finding is illustrated by means of an approbation of models with a case study involving a three-tier structure.

Further to this point, instead of additional revenues, a government is at a risk of a shrinking tax base and a reduction in budget revenues; and moreover from the perspective of national welfare, the additional loss of revenues and capital of MNCs. Therefore there is a significant importance in forming rules for MNC taxation policies which would focus not on taxes as such, but would focus on trying to keep capital within the territory and/or would facilitate the return of earlier divested income. This could be attempted, for example, by using the secondary adjustment rule in conjunction with a minimum tax on return.

The novelty of this research resides in the specificity of our investigation and the applicability of our conclusions to the practical challenges of international taxation and national revenue policies. The peculiarities of this economic moment and the crucial challenges for national governments in dealing with MNCs and the digital economy underline the significance of this study. Our results expand and develop the existing literature in this ever-crucial area be of immediate use to policymakers, academics and administrators involved in national and international taxation, finance, economics, and analysis.

Keywords: international taxation, economic-mathematical modeling, multinational company, tax planning, rules of controlled transactions, withdrawal of revenues, return of revenues, transfer pricing, national welfare

JEL classification: C620, F230, H320, G17, G18 


\section{Introduction}

The problems posed by the taxation of multinational companies (MNCs), and how to address these using economic-mathematical modeling, is constantly in the focus of scientists and practitioners. This entire area is naturally subject to the contingencies (and vagaries) of globalisation, with increased competition for capital, huge volumes of international trade [1, p. 10-11], transborder investment [2, p. 2] and influence of taxation policy on international capital flows all being significant influential variables. One of the recent examples of activity in this area is in the area of tax reform in the USA, which aims at providing conditions for repatriation of capital [3].

A range of empirical evaluations given in paper [4] shows that susceptibility to direct taxes is also a significant variable: a reduction in taxes by 1 percentage point results in an increase of foreign direct investment (FDI) by $3.72 \%$. Consequentially, over the course of time, FDI becomes more susceptible to taxes [4, p. 12].

This means that taxation of capital and income of MNCs, along with other factors, is a valuable reason which defines their flow. Due to the digital revolution and the accelerated development of cyber physical enterprises, transborder business activity has risen sharply. It influences intangible assets, users and business functions, and the flexibility of corporate entities in choosing the location of resources and capital [5, p. 33-34]. As such, new opportunities have arisen for building more effective systems of international trade and MNC tax expenditure reduction. This induced various governments to take measures towards counteracting new methods of tax avoidance and distortions of competition $[6 ; 18]$. The purpose of this research is to substantiate (on the basis of the author's economic-mathematical models) the most efficient measures of government taxation policy intended to clamp down on tax avoidance by MNCs that use transfer pricing (TP), and to devise a favourable taxation scheme for both keeping capital inside the country and attracting capital into it. Unlike our predecessors, we assess the influence of tax regulation on MNCs from the point of view of national welfare, taking into consideration the behaviour of MNCs in the area of taxation.

\section{Methods}

\section{Types of MNC Taxation Models}

A variety of MNC taxation models exist based on the neoclassical investment theory. These models are of special interest from the standpoint of achieving our goal in this study. According to the method of determination of economic equilibrium, we distinguish calculable equilibrium models $[4$, p. 155-181; 7; 8] from postulated equilibrium models $[9 ; 10 ; 11 ; 12]$. According to the types of financial structure, there are bilateral (direct) holding structure models and three-tier structure models with an intermediary (usually offshore) [4, p. 129; 7, p. 91-100]. In the case of economic equilibrium, there are tax rate equilib- rium models $[10 ; 11 ; 12]$, company income equilibrium models $[8 ; 9]$ and jurisdiction income equilibrium models [8].

H. Grubert [9] in his paper, uses a number of scenarios to simulate the events when the amount of payment of interest and royalty to the parent company is undervalued and the company's savings on tax is calculated. However, at the same time, the issue of shortfall in income of the home jurisdiction is not considered, and the possibility of income reverse adjustment by the government is not taken into consideration. The author does not analyse the possibility of company manipulation with active income. This makes it impossible to estimate the efficiency of the government counteracting the tax planning methods of MNCs from the point of view of the economic welfare of the country.

Paper [8] evaluates the influence of controlled company rules and thin capitalisation on the amount of MNC taxes and income from the standpoint of both the country's welfare and MNCs' welfare. However, this is approached as a common neoclassic assumption, i.e. of economic operators' maximising behaviour by means of differentiation on the basis of tax rates, and finding the extremum of the welfare function. There is no separation into active and passive income as concerns how different taxation approaches are applied. Besides, the formula [8, p. 10-12] does not take into account the fundamental rules of controlled transactions. For this reason, the model does not take into consideration the amount of divested and returned income and capital, thus impeding a realistic estimate of welfare concerns.

The fundamental research by the OECD [4] does not fully present the approach from the point of view of return of previously divested income. Six cases of tax planning are considered, mainly by means of in-company credit provision.

Our research develops the scientific-methodological approaches of D.W. Jorgenson [14], J. Whalley [10], H. Grubert [9], but it takes into consideration issues which have not been amply covered in their papers. The point at issue is an assessment of MNC tax planning countermeasures applied by governments of various countries. Against this background, we raise the problem of loyal jurisdictions, with taxation policy parameters that enable MNCs to avoid taxes divesting capital through their subsidiary companies.

In order to achieve the research goal, we offer to use postulated equilibrium simulation models analysing threetier financial structures (comprising subsidiary companies in loyal jurisdictions and affiliated persons in offshores). This approach aims to help take better account of the institutional factors, and describe the business situation using rather simple formulas, which are easier to interpret economically. We start with income equilibrium models for enterprises after tax (as basic ones) and then pass on to more complicated models with jurisdiction income equilibrium. This choice is explained by the fact that our 
approach aims at the correct determination of the final results of MNC taxation from the point of view of national economies when indicators of private and public sector of the economy are taken into consideration, characterising the total resources of economic development left in the country and those resources which are received from abroad.

\section{Economic Statement of the Problem and Description of MNC Taxation Models}

We analyse three tax jurisdictions: common - A (territory of the country from which the situation is estimated), loyal - B (with a weak anti-offshore legislation), and a tax haven - C. There is also a MNC - a parent company, resident of A's territory. This parent company opens a subsidiary company (the parent owns or controls more than $50 \%$ of its property) in a loyal jurisdiction $B$, which conducts active economic operations. We assume that tax planning methods of MNCs may change by means of using affiliated companies opened by the parent company (A) and the subsidiary company (B) (indirectly) in the tax haven $\mathrm{C}$. The territory of $\mathrm{C}$ is used to conceal income and avoid taxes, and as such there are no real business operations here. Companies may apply (or not apply, or apply with limitations) common methods of tax planning including transfer pricing. At another point, governments may employ corresponding countermeasures categorised herein as Special Anti-Avoidance Rules: first of all, controlled transactions rules and secondary adjustment rules intended to counteract tax avoidance using transfer pricing $[15 ; 16]^{1}$.

Let us introduce some designations. Assume that the net profit (income) margin of the parent company in country A is $D_{A}$, and the net profit (income) $\operatorname{margin}^{2}$ of the subsidiary company in country $\mathrm{B}$ is $D_{B}$. The condition of economic equilibrium is observed if

$D_{A}=D_{B} k_{B} ; \quad k_{B}>0$.

In the general case, as long as we have a simulation model, $D_{A} \neq D_{B}$. Our goal is to study the influence of taxation policy, therefore we proceed to an analysis of the situation when $k_{B}=1 \Rightarrow D_{A}=D_{B}$.

One of our research tools is factors. Arithmetically, they are a share of the total net profit (income) margin for which the company (applying transfer pricing) and the country (by means of controlled transaction rules) changes such income:
$\Delta \varphi=\left(\varphi_{c}-\varphi_{g}\right)$

where $\varphi_{c}=\frac{D^{\prime}}{D}-$ the corrigent factor which defines the

part of income $\left(D^{\prime}\right)$, divested by the company from tax with respect to the total amount of its taxable income $D$; $\varphi_{g}=\frac{D^{\prime \prime}}{D}-$ the adjusting factor which defines the part of income $\left(D^{\prime \prime}\right)$, returned by the government of the country to taxation against the total amount of the company taxable income $D$;

$\Delta \varphi$ - the resulting balance after such corrigent actions and adjustments (in the normal course of events $\varphi_{c} \geq \varphi_{g} \Rightarrow \Delta \varphi \geq 0$ ).

Let us define that hereinafter all $D$ are the normal net income margin generated on the basis of market prices, which later may be corrected by MNCs by the value of $D^{\prime}$ and then corrected back by the value of $D^{\prime \prime}$ by countries.

Types of income:

economic operations $D$ (comprises active and passive income taken into consideration in the formulas separately due to differences in their taxation);

passive income in the form of: dividends $D_{S}$, royalty $D_{R}$, interest $D_{I}$.

Tax rates:

$t_{A A}, t_{B B}$ - effective (average) tax rates for net profit (income $)^{3}[17$, p. 99];

$t_{A A}^{n}, t_{B B}^{n}$ - nominal rates of corporate income tax;

$t_{S_{B A A}}, t_{R_{B A A}}, t_{I_{B A A}}$ - effective rates of passive income tax (in this case - taxes paid by a subsidiary company from the loyal country B to the parent company to country A subject to taxation in country A - see suffix number BAA); these tax rates are obtained as a result of change of nominal rates for some reasons $\left(t_{X_{B A A}}=f\left(t_{X_{B A A}}^{n}\right)\right)$;

$t_{S_{B A B}}, t_{R_{B A B}}, t_{I_{B A B}}-$ nominal rates of tax on repatriation

of dividends, royalty, interest, correspondingly, which is withheld at source (in this case in country B - see suffix number BAB);

$t_{I_{A C A}}^{+}, t_{S_{A C A}}^{+}, t_{S_{B A A}}^{+}-$effective rates of supplementary taxes on some types of MNC income introduced by governments as tax avoidance countermeasures.

\footnotetext{
${ }^{1}$ The point of secondary adjustments is that the government tries to make up for losses related to retention of MNC income abroad, considering it as a kind of assets, and subject to taxation on imputed income.

${ }^{2}$ The net profit (income) margin may be expressed as relative values (as a percentage ratio of income from investments to the sum of such investments) and also as absolute values (as the sum of income earned on the preassigned sum of investments). For convenience of economic interpretation hereinafter we will interpret $\mathrm{D}$ as a certain sum of net profit (income) (for example, 100 y.e.) induced by such fixed investment amount.

${ }^{3}$ In this case, we understand the effective tax rate on net income as a certain equated percent of seizure of profits of a typical enterprise (enterpriserepresentative), under the influence of all taxes provided for in the national legislation (not just the corporate income tax). That is, in the interpretation of Paying Taxes: "Paying Taxes take into consideration all taxes and duties established by the government (at any level: federal, governmental or local), applied to standardised business and influencing its financial statements" [17, p. 99].
} 
According to OECD specialists [7, p. 14], from the point of view of an empirical evaluation of tax influence on FDI, historic average effective tax rates (AETR) give more relevant values and are a better predictor than predicted marginal effective tax rates (METR). They are all the more better than nominal tax rates established by law which do not take into consideration tax planning effects and special tax regimes. As such, the most general expression of the main tool used in modeling - AETR - becomes as follows:

$$
A E T R=\frac{D-D(1-\Delta \varphi)(1-t)}{D}=1-(1-\Delta \varphi)(1-t)
$$

provided that $D>0$.

When comparing AETR of countries A and B the equilibrium formula may be represented as follows:

$$
\begin{gathered}
\operatorname{AETR}_{A}=\operatorname{AETR}_{B}, \\
1-\left(1-\Delta \varphi_{A}\right)\left(1-t_{A}\right)=1-\left(1-\Delta \varphi_{B}\right)\left(1-t_{B}\right) .
\end{gathered}
$$

A similar formula was offered by H. Grubert [9], however in addition to the possibility of a correction of MNC income taken into consideration in his paper, we added the possibility of reverse correction of such income by the government. Further, we will compare not just tax rates in interacting countries (taking into consideration MNC correction and corrections made by governments) but rates of return (initially $D_{A}=D_{B}$ ) which remain available to enterprises of various countries:

$$
D_{A}\left(1-\Delta \varphi_{A}\right)\left(1-t_{A}\right)=D_{B}\left(1-\Delta \varphi_{B}\right)\left(1-t_{B}\right) .
$$

This and subsequent equilibrium formulas may be used to calculate the effective tax rates of the actually earned income and to substantiate the conclusions on the policy directions. Further analysis is dedicated to evaluation of changes of underlying situations under the influence of tax planning methods of MNC and countermeasures taken by the governments - i.e. controlled transactions rules.

\section{General Formula of Calculation of Income from the Standpoint of MNC Taking into Consideration Divested Income}

In a general way the income of the parent company in country A (or a similar subsidiary company in country B) may be represented as follows:

$$
\begin{aligned}
& D^{c}=D(1-\Delta \varphi)(1-t)=D-D \Delta \varphi- \\
& -D t+D \Delta \varphi t=D-F-T^{g}+T^{c+} .
\end{aligned}
$$

The income of the company remaining in this country $\left(D^{c}\right)$ is defined as total income $(D)$ net of divested "grey" income $(F)$ and tax paid $\left(T^{g}\right)$ plus the sums saved by MNC by means of tax planning $\left(T^{c+}\right.$ ) (in other words - government's losses).

From the point of view of MNC net income, formula (6) is incomplete, as it does not take into consideration the share of divested income of MNC. In order to make a more accurate calculation of the total income of MNCs, and to evaluate the economic equilibrium taking into consideration the offshore factor expression (6) should be increased by $F$, which characterises the share of income divested to offshore C:

$$
\begin{aligned}
& D_{\text {all }}^{c}=D^{c}+F=D(1-\Delta \varphi)(1-t)+ \\
& +D \Delta \varphi=(D-F)-\left(T^{g}-T^{c+}\right)+F .
\end{aligned}
$$

Income transferred to offshore $\mathrm{C}$ is actually $\mathrm{MNC}$ income divested from these countries in order to reduce the taxable base. Undervaluation by MNCs of the goods' market value by the part of the total income $\varphi_{A C}$ when exporting from country A to country $\mathrm{C}$ helps to shrink the taxable base in the native country $D_{A}\left(1-\varphi_{A C}\right)$, and to increase income in the offshore $\mathrm{C}$ by the same value $D_{A} \varphi_{A C}$, because the goods will be sold later at the market price and the non-taxable margin will stay in the offshore C. Even if we take into account that governments using controlled transaction rules may correct income for taxation purposes, the untaxed income will amount to $D_{A} \Delta \varphi_{A C A}$, where $\Delta \varphi_{A C A}=\varphi_{A C}-\varphi_{A C A}$, and $\varphi_{A C A}-$

amount of correction of the divested income by country A. Now such income may also be a "grey" income and (or) "grey" capital which does not return to the country's economy later, makes no positive contribution in the native country, and is in fact used in the economy of other countries. Consequently, application of the corrections methods within controlled transaction rules from the standpoint of national welfare may be ineffective, even if the government completely reestablishes the taxable base. In this case, corrections will be made only for the taxation purposes: $\Delta \varphi_{A C A}=\varphi_{A C}-\varphi_{A C A}=0$, however from the point of view of counter-action, of income outflow, or its return, they are inefficient: $\varphi_{A C A}=0$. Consequently, $\Delta \varphi_{A C A}=\varphi_{A C}$, and income outflows from the country in full. In such scenarios the non-returned "grey" income: $F_{A}=D_{A} \varphi_{A C}+D_{A} \varphi_{R_{A C}}+D_{A} \varphi_{I_{A C}}+D_{R_{C A}} \varphi_{R_{C A}}+D_{I_{C A}} \varphi_{I_{C A}}$ is the result of application by MNCs of transfer pricing methods as regards active transactions $\left(D_{A} \varphi_{A C}\right)$, as well as passive income $\left(D_{A} \varphi_{R_{A C}}, D_{A} \varphi_{I_{A C}}, D_{R_{C A}} \varphi_{R_{C A}}, D_{I_{C A}} \varphi_{I_{C A}}\right)$. Now the reasons why MNC operations have a negative impact on the economy of country $A$ become clear: a significant part of capital is absorbed irretrievably into offshore $C$, and the income which remains in the country is reduced even more by the supplementary tax. Further we will consider a complicated situation taking into consideration repatriation taxes and passive income.

\section{Explicit Model of Income Equilibrium from the Standpoint of MNC, taking Divested Income into Consideration Let us consider a more general scenario in which:}

1) the parent company invested in tangible and intangible assets of a subsidiary company, and also disbursed a loan to it (purchased debt securities). The income earned by 
the subsidiary company in country $B$ is repatriated in the form of dividends $D_{S}$, royalty $D_{R}$ and interest $D_{I}$ to country A. The parent company may also get intangible assets and loans from the subsidiary company and, consequently, the parent company pays royalties and interests to the subsidiary;

2) the parent and a subsidiary company conduct active and passive transactions with affiliated companies opened in offshore $C$, but along with this they do not make direct investments in these companies, so the company in offshore $C$ pays no dividends to companies in country $A$ and B. All economic relations in combinations A-C and B-C are limited by crediting and transfer of intangible assets from the company from offshore $C$ to the companies from countries $\mathrm{A}$ and $\mathrm{B}$ and, consequently, by payment of royalty and interests to offshore $C$ as well as by back-to-back similar transactions of C-A and C-B;

3) the parent and a subsidiary company carry out economic operations using transfer pricing through an affiliated company in offshore $C$. This helps to correct the tax base for a certain part of the rate of return. The governments restore the taxable base. In this case, the tax equilibrium model becomes as follows:

$D_{A}^{\text {all }}=D_{B}^{\text {all }}$

or

$D_{A}^{m}+D_{S_{A B}}^{p}+D_{C A}^{p}+F_{A C}=D_{S_{B A}}^{m}+D_{B A}^{p}+D_{S_{C B}}^{p}+F_{B C}$,

where $D_{A}^{m}, D_{S_{B A}}^{m}$ - the net income from active business operations of the parent and subsidiary company in countries $\mathrm{A}$ and $\mathrm{B}$, respectively;

$D_{C A}^{p}, D_{S_{C B}}^{p}$ - the net passive income received, respectively, by the parent and subsidiary company from affiliated companies from offshore $\mathrm{C}$;

$D_{B A}^{p}, D_{S_{A B}}^{p}$ - the net passive income received by the parent and subsidiary company, respectively, from each other;

$F_{A C}, F_{B C}$ - the total amount of "grey" income divested by the parent and subsidiary company (from all active and passive transactions) to offshore $C$ net of passive income repatriation taxes (see Note 1).

It is clear from the presented equilibrium model that the amount of divested passive income is reduced by its repatriation tax. The amount of income divested from country $A$ to offshore $C$ will be

$$
\begin{aligned}
& F_{A C}=D_{A} \varphi_{A C A}+D_{A} \varphi_{R_{A C A}}+D_{A} \varphi_{I_{A C A}}+ \\
& +D_{R_{C A}} \varphi_{R_{C A A}}+D_{I_{C A}} \varphi_{I_{C A A}}- \\
& -\left(D_{A} \varphi_{R_{A C}} t_{R_{A C A}}+D_{A} \varphi_{I_{A C}} t_{I_{A C A}}\right) .
\end{aligned}
$$

In this scenario, we proceed from the premise of the equilibrium of $\mathrm{MNC}$ income earned in countries A and B, regardless of the company which owns it (plus the income gained from offshore $C$ ). Further, we will consider the problem from another point of view - from the standpoint of national welfare of country $A$.

\section{National Welfare Model in Case of Divestment of MNC Income to Offshore}

All the models considered above are preliminary, they evaluate economic interests from the MNC point of view. National interests are much more than interests of economic operators from the private sector. Here, we should give consideration only to the income which pertains to the territory of a certain country acting as the source of wealth (e.g. financing of labour and capital, social sector etc.). Approaching the problem this way changes the logic of the mathematical modeling significantly. In the simplest case, the function of national welfare may be defined as follows: $D^{\mathrm{w}}=D(1-\Delta \varphi)(1-t)+D(1-\Delta \varphi) t=D^{c}+T$.

The fundamental difference of this model from the basic model (5) consists in the fact that in this case, net income is taken into consideration along with taxes imposed by governments. In a more general situation, considering three countries as sources of income - A, B and C, the national welfare of country $A$ is defined as follows:

$D_{A B C}^{w}=D_{A B C}^{c}+T$,

where $D_{A B C}^{c}$ - the sum of income gained from three countries (unlike previous scenarios where only the company income from the country of incorporation and offshore $C$ was taken into consideration. The total income of country $A$, taking into consideration tax revenues of the government amounts to the following:

$$
\begin{aligned}
& D_{A B C}^{\tilde{\boldsymbol{w}}}=D_{A B C}+T= \\
& =D_{A}^{m}+\left(D_{S_{B A}}^{m}+D_{S_{C B}}^{p}+D_{S_{A B}}^{p}+D_{B A}^{p}\right)+D_{C A}^{p}+T_{A B C}^{g}-T_{A B C}^{c+},
\end{aligned}
$$

where income $D_{S_{B A}}^{m}, D_{S_{C B}}^{p}, D_{S_{A B}}^{p}$ are dividends received by the parent company from the subsidiary company (income is divided into component parts due to the specific character of its accrual).

Taxes collected by the government of country $A$ consist of taxes imposed on the income gained in countries $A, B$ and $\mathrm{C}$, and of the taxes repatriated to countries $\mathrm{B}$ and $\mathrm{C}$, reduced by the amounts saved by MNCs due to tax planning.

$$
\begin{aligned}
& T=T_{A B C}^{g}-T_{A B C}^{c+}=\left(T_{A}^{m}+T_{A C A}^{p}+T_{A B A}^{p}\right)+ \\
& +\left(T_{S_{B A A}}^{m}+T_{S_{C B A}}^{p}+T_{S_{A B A}}^{p}+T_{B A A}^{p}\right)+T_{C A A}^{p}= \\
& =\left[\left(T_{A C}^{m}-T_{A C}^{m+}\right)+\left(T_{I_{A C A}}^{I}+T_{R_{A C A}}^{R}\right)+\left(T_{I_{A B A}}^{I}+T_{R_{A B A}}^{R}\right)\right]+ \\
& +\left[\left(T_{S_{B A A}}^{m}-T_{S_{B A A}+}^{m+}\right)+\left(\left(T_{S_{B A A}}^{I_{C B}}+T_{S_{B A A}}^{R_{C B}}\right)-\left(T_{S_{B A A}}^{I_{C B}+}+T_{S_{B A A}}^{R_{C B}+}\right)+\right.\right. \\
& \left.+\left(T_{S_{B A A}}^{I_{A B}}+T_{S_{A A A}}^{R_{A B}}\right)+\left(T_{I_{B A A}}^{I_{B A}}+T_{R_{B A A}}^{R_{B A}}\right)\right]+ \\
& +\left[\left(T_{C A}^{I}+T_{C A}^{R}\right)-\left(T_{C A}^{I+}+T_{C A}^{R+}\right)\right] .
\end{aligned}
$$

Thus, the national welfare model of country $A$ becomes an equation:

$$
D_{A B C}^{w 1}=D_{A B C}^{w 2} \text {. }
$$

Its economic meaning is that the total incomes of country $A$ earned from sources in countries A, B, and C in various case scenarios are compared on the basis of specific features of MNC tax minimisation methods and countermeasures taken by the governments. 


\section{Calculations and Results}

Let us consider specific examples which show how the presented models function. We take Russia (RF) as the home country $A$. Assume that the parent company from RF works with the loyal territory $B$ (Laos) where it has a subsidiary company. The parent and subsidiary company cooperate with affiliated offshore companies from country $C$ - British Virgin Islands (BVI) which imposes no taxes on foreign income.

In Laos, the taxes are comprised of:

effective tax $-t_{B B}=26 \%$ [17];

tax on interests received from abroad -

$t_{I_{A B B}}=t_{I_{C B B}}=24 \%$, royalty $t_{R_{A B B}}=t_{R_{C A A}}=24 \%$;

tax on dividends repatriation $-t_{S_{B A B}}=10 \%$, interest

$t_{I_{B A B}}=t_{I_{B C B}}=10 \%$, royalty $t_{R_{B A B}}=t_{R_{B C B}}=10 \%$.

In RF the taxes consist of:

effective tax $-t_{A A}=48 \%$ [17];

tax on dividends received from a foreign company

- $t_{S_{B A A}}=13 \%$, interest $t_{I_{B A A}}=t_{I_{C A A}}=20 \%$, royalty

$t_{R_{B A A}}=t_{R_{C A A}}=20 \%$;

tax on dividends repatriation $-t_{I_{A B A}}=t_{I_{A C A}}=20 \%$, royalty $t_{R_{A B A}}=t_{R_{A C A}}=20 \%$.

We assume that the total rate of return in countries A and $\mathrm{B}$ is equivalent and amounts to 100 units. Taking into consideration the application in RF of the controlled transaction rule we presume that the government for the purpose of taxation restores $100 \%$ of divested taxes or $\varphi_{g}^{A}=1$. The government of Laos does not apply the controlled transaction rule, hence, it does not correct taxes, i.e. $\varphi_{g}^{B}=0$. Let us also assume that that the parent and subsidiary companies correct and divest in a "grey" way 20 units of active income to offshore $C$, and 5 units of royalty and interest in each of the following cases: from country $A$ to country $C$, from country $B$ to country $C$, from country $C$ to country A and from country C to country B. Apart from that, we assume that 5 units of passive income (royalty, interest) are transferred from country $\mathrm{C}$ to $\mathrm{A}$ and the same amount - from country C to B. We presume that Laos and RF have signed a double taxation treaty. From the standpoint of an MNC, we insert values into (8) and obtain the following:

$$
\begin{aligned}
& D_{A}^{m}+D_{S_{A B}}^{p}+D_{C A}^{p}+F_{A C}=D_{S_{B A}}^{m}+D_{B A}^{p}+D_{S_{C B}}^{p}+F_{B C}+\Delta ; \\
& (70,0-30,0-33,6)+(10,0-3,4)+(20,0-10,0-4,0)+ \\
& +(40,0-2,0)=(70,0-30,0-24,9+10,7)+(10-2)+ \\
& +(20-10-5,4+2,7)+(40,0-1,0)+\Delta ; \\
& 6,4+6,6+6+38,0=25,8+8+7,3+39,0+\Delta ; \\
& 19,0+38,0=41,0+39,0+\Delta \\
& \Delta=-23,0 .
\end{aligned}
$$

The results of these calculations show that with such initial data it is obviously economically beneficial to invest in the subsidiary company in Laos because income after taxes is much greater than the income earned at home (41.0>19.0 units). When taking into consideration the "grey" income (38.0 and 39.0 units) delta remains almost unchanged (23.0 units while it was 22.0 units). The advantages of opening a subsidiary company in Laos are contingent upon the fact that the home jurisdiction, applying the controlled transaction rules, additionally imposes taxes on divested income of 16.4 units (or gives no opportunity to save on taxes, as is permitted in Laos) and there is a smaller effective tax rate in Laos. The amount of divested income is approximately equal (it was reduced insignificantly by the repatriation tax: in country A - by 2 units, in country B - by 1 unit). Due to the subsidiary company's manipulations with taxes the government of country $B$ receives in its budget less than due taxes amounting to 12.7 units. Besides, the government of country $A$ loses 0.7 units of the dividend tax. As a result, MNC saves 13.4 units, which amounts to almost $7 \%$ of all its income from three territories (total income is 200 units).

Thus, controlled transaction rules applied by the government of country $A$ has no impact on the amount of income which remains with the parent company. The amounts of income divested by the company are approximately equal to the indicators of the subsidiary company in Laos, although its government does not introduce restrictive rules. The situation becomes even worse for the parent company due to additional taxation introduced by the government of country $A$.

Analysing the situation from the point of view of national welfare, one may draw substantially varying conclusions. Let us here make calculations with the parameters of variables identical to the previous scenario inserting them in (14) (see Note 1):

$$
\begin{aligned}
& D_{A B C}^{w 1}=D_{A B C}^{w 2}+\Delta ; \\
& 6,4+(25,8+7,2+6,6+8)+6+(44,5-0,7)= \\
& =20,8+(25,8+7,2+6,6+8)+8+(44,5-17,1)+\Delta ; \\
& 6,4+47,6+6+43,8=20,8+47,6+8+27,4+\Delta ; \\
& 60,0+43,8=76,4+27,4+\Delta ; \\
& 103,8=103,8+\Delta ; \\
& \Delta=0 .
\end{aligned}
$$

In the first case (if $A$ applies the controlled transaction rules), the total income of country $A$ from operations of the company in countries A, B, C amounts to 103.8 units including tax proceeds of the government of 43.8 units; and the parent company income amounts to 60,0 units (obtained from $\mathrm{A}-6.4, \mathrm{~B}-47.6$ (including the dividends of 39.6), C - 6.0).

In the second case (if $A$ does not apply the controlled transaction rules) the total income of country $A$ from operations of the company in countries A, B, C has not changed in general and amounts to 103.8 units but it was redistributed between MNC and the government as follows: tax proceeds of the government of 27.4 units; and the parent company income amounts to 76.4 units (obtained from $\mathrm{A}-20.8, \mathrm{~B}-47.6$ (including the dividends of 39.6), C - 8.0). 
It is now becoming apparent that the controlled transaction rules from the point of view of national welfare of country $A$ are inoperative because in general the income has not changed $(\Delta=0)$. In both scenarios the total "grey" income divested into offshore $\mathrm{C}$ remained unchanged and amounted to 77.0 units (from A - 38.0, from $B$ - 39.0). If country A had avoided losses or had returned income from offshore $\mathrm{C}$ its income from territories $\mathrm{A}, \mathrm{B}$ and $\mathrm{C}$ would have been 180.8 units.

Calculations show that if the government of the home jurisdiction fails to return capital or prevent its divestiture, the total income of countries A and B net of taxes will amount to 60.0 and this is significantly fewer than "grey" income in offshore $\mathrm{C}$ of 77 units. Apart from that, governments of countries A and B lose 13.4 units of taxes (and this when the government of country $A$ applies controlled transaction rules which restore the tax base to some extent but in general are ineffective as a method of return of "grey" income). Applying the controlled transaction rules, country $A$ returned 16.4 units of income in the form of taxes, but this is out of proportion to the fact that country A lost 77 units of divested "grey" income (including the income not returned to country B which finally would have been received by country A as dividends). Eventually, the income of country $A$, in spite of the controlled transaction rules, is reduced by almost half (from 180.8 to 103.8 units). As a result of the problems in defining market prices and, correspondingly, with the efficiency of use of the controlled transaction rules for operations with intangible assets $\varphi_{g}^{A} \rightarrow 0$, in addition, country A may lose income consisting of restored taxes. This means that it is necessary to improve the controlled transaction rules for intangible assets.

\section{Discussion}

Our calculations show differences in the considered issues: from the point of view of MNCs, global net and "grey" MNC income is evaluated, whereas from the standpoint of national welfare only the income of MNC and governments which is aimed at satisfaction of the needs of such country is evaluated.

From the point of view of countries, the most important is the return of divested "grey" income. After all, from the standpoint of total income of MNC income is not just divested from tax but is also transferred to other countries. However, in this case MNC income is not reduced but rather increased by the amount of saved taxes. From the point of view of national welfare the income divested by MNCs decreases a country's income significantly and restored taxes (even in full) cannot reimburse for such losses.

Our predecessors (see for example [9, p. 23-24; 19; 20; 21; 22]) have already given substantiated recommendations for MNC taxation improvement, in particular, concerning application of the proportionate multijurisdictional taxation method [23]. However, in the majority of papers the main attention was focused on the problems of tax avoidance and the correction of income by companies. We have a different view, since the problem consists not so much in the government tax income as in the income and capital of MNC which is divested and fails to participate in improvement of national welfare.

The main conclusion of H. Grubert [9] stated that the strategies of MNCs, in using aggressive tax planning schemes (first of all, in operations with intangible assets), exercised a decisive influence on the effective tax burden for transborder investments. The determining approach in the behaviour of the receiving country may be the approach of governments in which imposing tax burden on various types of companies depends on their contribution to national welfare. We agreed with the author and moved on focusing the main attention on an assessment of MNC actions from the point of view of national welfare and considering the efficiency of tax planning countermeasures taken by governments (H. Grubert does not consider this issue).

From the standpoint of the approach we offer, we emphasise the importance of creating such rules of MNC tax planning counteracting which would not focus on taxes as such, but would rather stimulate the preservation of capital in a certain territory and (or) would facilitate return of previously divested income. In this context, it is reasonable to introduce in Russia the secondary adjustment rule in combination with minimal taxation when income is returned to the country.

\section{Conclusion}

One of the main problems of MNC taxation is a tax-free outflow of MNC capital and income as a result of their use of tax planning methods related to development of the digital economy. In order to substantiate the ways of MNC tax planning counteraction and to create a national taxation regime that is favourable for preserving and attracting capital, we developed economic-mathematical models which evolve the approaches of our predecessors. The main new special characteristics of the models we offer consist of the following:

1. The approach is intended to define the eventual outcome of international taxation from the standpoint of national economies, where indicators of the private (economic entities) as well as public (government) economy sectors (which characterise the total resources of economic development remaining in the country and received from abroad) are taken into consideration;

2. The measures of MNC tax planning as well as countermeasures taken by the government are taken into consideration together.

Approbation of the developed models, as exemplified by application of the controlled transaction rule which is fundamental for anti-avoidance measures taken against MNC, showed the following:1. From the standpoint of the economic interests of MNCs, the government's stern 
measures (such as controlled transaction rules) may have a direct negative effect: the better the rules work, the less income is left at the company's disposal within the home jurisdiction, as it is redistributed in favour of the government in the form of taxes. Therefore, an MNC is interested in expanding its activities within the loyal of offshore jurisdictions to the disadvantage of the home jurisdiction. This helps to circumvent the controlled transaction rules. For the government, the eventual outcome of application of the controlled transaction rules may be negative: a shrinking tax base and revenue suppression. From the standpoint of national welfare, the outcome is even more negative, as the country may lose MNC income, capital, and tax proceeds.

The controlled transaction rules essentially work poorly with intangible assets, since it is very difficult to justify their "market" price within the conditions of a digital economy. MNCs may always find mechanisms which help to avoid taxation of a part of income applying the transfer pricing methods for intangible assets. Therefore, national welfare will decline for tax reasons too. It is necessary to consider carefully whether more strictly controlled transaction rules should be invented or significant tax preferences should be granted to certain types of business activity.

2. The national taxation policy as regards MNC depends strongly on taxation policies of other countries, so while loyal countries and offshores exist in the world, strict controlled transaction rules in the home country A (connective A-C) may fail because capital may go away, taking the route A-B-C. This puts the problem of global coherence of taxation rules front and centre in terms of international economic significance.

3. The problem is not only one of taxes as such, and their distribution among national jurisdictions. If, for example, taxes are assessed additionally for MNC in country A but the capital actually divested before was not returned to country A from countries B and C, it makes no economic sense. This is because it does not increase the national welfare of country A, but merely redistributes GDP between the private sector and the government in favour of the government.

4. In order to substantiate a taxation regime favourable for economic growth we should develop the offered approach from the point of view of national welfare, which requires taking into consideration the global income of MNC and its distribution among jurisdictions (including an application of the proportionate formular method). In the long run, taxes are not in and of themselves as important as the location where the real capital is situated, where it operates financially, and where employment opportunities are provided, innovations are generated etc.

Our conclusions are preliminary, and further studies are necessary. A common logic may consist in the expansion of parameterisation of models in order to carry out a set of computational experiments with different typical versions of change within the rules of governmental regula- tion of MNC taxation. In this context, emphasis should be placed, in particular, on income and capital flows and the relevant considerations of national welfare.

\section{Note 1. Interpretation of Elements of Formulas in Equilibrium Models}

$$
\begin{aligned}
& D_{A}^{m}=D_{A C}^{m}-F_{A C}^{m}-T_{A C}^{m}+T_{A C}^{m+}= \\
& =\left\{D_{A}\left(1-d_{R_{A B}}-d_{I_{A B}}-d_{R_{C A}}-d_{I_{C A}}\right)\right\}- \\
& -\left\{D_{A} \varphi_{A C}+D_{A}\left(\varphi_{R_{A C}}+\varphi_{I_{A C}}\right)\right\}- \\
& -\left\{\left[D_{A}\left(1-d_{R_{A B}}-d_{I_{A B}}-d_{R_{C A}}-d_{I_{C A}}\right)\right] t_{A A}\right\}+ \\
& +\left\{D_{A} \Delta \varphi_{A C A} t_{A A}+D_{A}\left(\Delta \varphi_{R_{A C A}}+\Delta \varphi_{I_{A C A}}\right) t_{A A}\right\} \text {; } \\
& D_{S_{A B}}^{p}=D_{S_{A B}}^{p}-T_{A B A}^{p}-T_{A B B}^{p}-T_{S_{B A B}}^{p_{A B}}-T_{S_{B A A}}^{p_{A B}}=\left[D_{S_{A B}}^{I}+D_{S_{A B}}^{R}\right]- \\
& -\left[T_{I_{A B A}}^{I}+T_{R_{A B A}}^{R}\right]-\left[T_{I_{A B B}}^{I}+T_{R_{A B B}}^{R}\right]-\left[T_{S_{B A B}}^{I}+T_{S_{B A B}}^{R}\right]- \\
& -\left[T_{S_{B A A}}^{I}+T_{S_{B A A}}^{R}\right]=\left\{D_{R_{A B}}+D_{I_{A B}}\right\}-\left\{D_{R_{A B}} t_{R_{A B A}}+D_{I_{A B}} t_{I_{A B A}}\right\}- \\
& -\left\{D_{R_{A B}} t_{R_{A B B}}+D_{I_{A B}} t_{I_{A B B}}\right\}-\left\{D_{R_{A B}}\left(1-t_{R_{A B A}}-t_{R_{A B B}}\right) t_{S_{B A B}}+\right. \\
& \left.+D_{I_{A B}}\left(1-t_{I_{A B A}}-t_{I_{A B B}}\right) t_{S_{B A B}}\right\}-\left\{D_{R_{A B}}\left(1-t_{R_{A B A}}-t_{R_{A B B}}\right) t_{S_{B A A}}+\right. \\
& \left.+D_{I_{A B}}\left(1-t_{I_{A B A}}-t_{I_{A B B}}\right) t_{S_{B A A}}\right\} \text {; } \\
& D_{C A}^{p}=\left[D_{C A}^{p}-F_{C A}^{p}-T_{C A}^{p}\right]=\left[D_{C A}^{I}+D_{C A}^{R}\right]-\left[F_{C A}^{I}+F_{C A}^{R}\right]- \\
& -\left[T_{C A}^{I}+T_{C A}^{R}\right]+\left[T_{C A}^{I+}+T_{C A}^{R+}\right]=\left\{D_{R_{C A}}+D_{I_{C A}}\right\}- \\
& -\left\{D_{R_{C A}} \varphi_{R_{C A}}+D_{I_{C A}} \varphi_{I_{C A}}\right\}-\left\{D_{R_{C A}} t_{R_{C A}}+D_{I_{C A}} t_{I_{C A}}\right\}+ \\
& +\left\{D_{R_{C A}} \Delta \varphi_{R_{C A A}} t_{R_{C A}}+D_{I_{C A}} \Delta \varphi_{I_{C A A}} t_{I_{C A}}\right\} \text {; } \\
& F_{A C}=\left[\left(F_{A C}^{m}-T_{A C A}^{p}+F_{C A}^{p}\right)\right]=\left[\left(F_{A C}^{m}-\left(T_{I_{A C A}}^{I}+T_{R_{A C A}}^{R}\right)+\right.\right. \\
& \left.\left.+F_{\tilde{\mathscr{A}} A \bar{R}^{+}}^{I} F_{C A}^{R}\right)\right]_{\bar{A}}=\left\{\left[D_{A} \varphi_{A C}+D \varphi_{\tilde{N}}+D \varphi_{A \tilde{N}}\right]-\right. \\
& \left.-\left(D_{A} \varphi_{R_{A C}} t_{R_{A C A}}+D_{A} \varphi_{R_{A C}} t_{R_{A C A}}\right)\right\}+\left\{D_{I_{C A}} \varphi_{I_{C A}}\right\}+\left\{D_{R_{C A}} \varphi_{R_{C A}}\right\} \\
& D_{S_{B A}}^{m}=D_{B C}^{m}-F_{B C}^{m}-\left[T_{B C}^{m}-T_{B C}^{m+}\right]-\left[T_{S_{B A B}^{m}}^{m}-T_{S_{B A B}^{m+}}^{m+}\right]- \\
& -\left[T_{S_{B A A}}^{m}-T_{S_{B A A}^{m+}}^{m+}\right]=\left\{D_{B}\left(1-d_{R_{B A}}-d_{I_{B A}}-d_{R_{C B}}-d_{I_{C B}}\right)\right\}- \\
& -\left\{D_{B} \varphi_{B C}+D_{B} \varphi_{R_{B C}}+D_{B} \varphi_{I_{B C}}\right\}- \\
& -\left\{\left[D_{B}\left(1-d_{R_{B A}}-d_{I_{B A}}-d_{R_{C B}}-d_{I_{C B}}\right) t_{B B}\right]-\right. \\
& \left.-\left[D_{B} \Delta \varphi_{B C B} t_{B B}+D_{B} \Delta \varphi_{R_{B C B}} t_{B B}+D_{B} \Delta \varphi_{I_{B C B}} t_{B B}\right]\right\}- \\
& -\left\{\left[D_{B}\left(1-d_{R_{B A}}-d_{I_{B A}}-d_{R_{C B}}-d_{I_{C B}}\right)\left(1-t_{B B}\right) t_{S_{B A B}}\right]-\right. \\
& -\left[D_{B} \Delta \varphi_{B C B}\left(1-t_{B B}\right) t_{S_{B A B}}+D_{B} \Delta \varphi_{R_{B C B}}\left(1-t_{B B}\right) t_{S_{B A B}}+\right. \\
& \left.\left.+D_{B} \Delta \varphi_{I_{B C B}}\left(1-t_{B B}\right) t_{S_{B A B}}\right]\right\}- \\
& -\left\{\left[D_{B}\left(1-d_{R_{B A}}-d_{I_{B A}}-d_{R_{C B}}-d_{I_{C B}}\right)\left(1-t_{B B}\right) t_{S_{B A A}}\right]\right. \\
& -\left[D_{B} \Delta \varphi_{B C B}\left(1-t_{B B}\right) t_{S_{B A A}}+D_{B} \Delta \varphi_{R_{B C B}}\left(1-t_{B B}\right) t_{S_{B A A}}+\right. \\
& \left.\left.+D_{B} \Delta \varphi_{I_{B C B}}\left(1-t_{B B}\right) t_{S_{B A A}}\right]\right\} \text {; }
\end{aligned}
$$




$$
\begin{aligned}
& D_{B A}^{p}=D_{S_{B A}}^{I}+D_{S_{B A}}^{R}-\left[T_{I_{B A B}}^{I}+T_{R_{B A B}}^{R}\right]-\left[T_{I_{B A A}}^{I}+T_{R_{B A A}}^{R}\right]= \\
& =D_{I_{B A}}+D_{R_{B A}}-\left\{D_{I_{B A}} t_{I_{B A B}}+D_{R_{B A}} t_{R_{B A B}}\right\}-\left\{D_{I_{B A}} t_{I_{B A A}}+\right. \\
& \left.+D_{R_{B A}} t_{R_{B A A}}\right\} \text {; } \\
& D_{S_{C B}}^{p}=D_{C B}^{I}+D_{C B}^{R}-\left[F_{C B}^{I}+F_{C B}^{R}\right]-\left[T_{C B}^{I}+T_{C B}^{R}\right]+ \\
& +\left[T_{C B}^{I+}+T_{C B}^{R+}\right]-\left[T_{S_{B A B}^{I}}^{I_{C B}}+T_{S_{B A B}}^{R_{C B}}\right]+\left[T_{S_{B A B}}^{I_{C B}{ }^{+}}+T_{S_{B A B}}^{R_{C B}{ }^{+}}\right]- \\
& -\left[T_{S_{B A A}}^{I_{C B}}+T_{S_{B A A}}^{R_{C B}}\right]+\left[T_{S_{B A A}}^{I_{C B}+}+T_{S_{B A A}}^{R_{C B}+}\right]= \\
& =D_{I_{C B}}+D_{R_{C B}}-\left\{D_{I_{C B}} \varphi_{I_{C B}}-D_{R_{C B}} \varphi_{R_{C B}}\right\}- \\
& -\left\{D_{I_{C B}} t_{I_{C B}}+D_{R_{C B}} t_{R_{C B}}\right\}+ \\
& +\left\{D_{I_{C B}} \Delta \varphi_{I_{C B B}} t_{I_{C B}}+D_{R_{C B}} \Delta \varphi_{R_{C B B}} t_{R_{C B}}\right\}- \\
& -\left\{\left[\left(D_{I_{C B}}-D_{I_{C B}} t_{I_{C B}}-D_{I_{C B}} \Delta \varphi_{I_{C B B}}\right) t_{S_{B A B}}\right]+\right. \\
& \left.+\left[\left(D_{R_{C B}}-D_{R_{C B}} t_{R_{C B}}-D_{R_{C B}} \Delta \varphi_{R_{C B B}}\right) t_{S_{B A B}}\right]\right\}+ \\
& +\left\{\left[\left(D_{I_{C B}} \Delta \varphi_{I_{C B B}} t_{I_{C B}}\right) t_{S_{B A B}}\right]+\left[\left(D_{R_{C B}} \Delta \varphi_{R_{C B B}} t_{R_{C B}}\right) t_{S_{B A B}}\right]\right\}- \\
& -\left\{\left[\left(D_{I_{C B}}-D_{I_{C B}} t_{I_{C B}}-D_{I_{C B}} \Delta \varphi_{I_{C B B}}\right) t_{S_{B A A}}\right]+\right. \\
& \left.+\left[\left(D_{R_{C B}}-D_{R_{C B}} t_{R_{C B}}-D_{R_{C B}} \Delta \varphi_{R_{C B B}}\right) t_{S_{B A A}}\right]\right\}+ \\
& +\left\{\left[\left(D_{I_{C B}} \Delta \varphi_{I_{C B B}} t_{I_{C B}}\right) t_{S_{B A A}}\right]+\left[\left(D_{R_{C B}} \Delta \varphi_{R_{C B B}} t_{R_{C B}}\right) t_{S_{B A A}}\right]\right\} \\
& F_{B C}=\left[\left(F_{B C}^{m}+F_{C B}^{I}+F_{C B}^{R}\right)\right]=\left[\left(F_{B C}^{m}-\left(T_{I_{B C B}}^{I}+T_{R_{B C B}}^{R}\right)+\right.\right. \\
& \left.\left.+F_{C B}^{I}+F_{C B}^{R}\right)\right]=\left\{\left[D_{B} \varphi_{B C}+D_{B} \varphi_{R_{\tilde{X}}}+D_{B} \varphi_{b \tilde{N}}\right]-\right. \\
& \left.-\left(D_{B} \varphi_{R_{B C}} t_{R_{B C B}}+D_{B} \varphi_{R_{B C}} t_{R_{B C B}}\right)\right\}+\left\{D_{I_{C B}} \varphi_{I_{C B}}\right\}+\left\{D_{R_{C B}} \varphi_{R_{C B}}\right\}
\end{aligned}
$$

\section{References}

1. World trade statistical review 2017. Geneva: World Trade Organization; 2017. 177 p. URL: https://www. wto.org/english/res_e/statis_e/wts2017_e/wts2017_e. pdf

2. World investment report 2017: Investment and the digital economy. Geneva: United Nations Conference on Trade and Development; 2017. 237 p. URL: https://unctad.org/en/PublicationsLibrary/wir2017_ en.pdf

3. Feldstein M. The international consequences of US tax reform. Project Syndicate. Sept. 27, 2017. URL: https://www.project-syndicate.org/commentary/ united-states-tax-reform-international-impact-bymartin-feldstein-2017-09?barrier=accesspaylog

4. Tax effects on foreign direct investment: Recent evidence and policy analysis. OECD Tax Policy Studies. 2017;(17). URL: https://www.oecd-ilibrary. org/taxation/tax-effects-on-foreign-directinvestment_9789264038387-en

5. BEPS action 1: Address the tax challenges of the digital economy. 24 March 2014 - 14 April 2014. Public Discussion Draft. Paris: OECD; 2014. 81 p.
URL: https://www.oecd.org/ctp/tax-challengesdigital-economy-discussion-draft-march-2014.pdf

6. Addressing the tax challenges of the digital economy. Action 1: 2015 Final report. OECD/G20 Base erosion and profit shifting project. Paris: OECD Publ.; 2015. 285 p. DOI: $10.1787 / 9789264241046$-en

7. Addressing base erosion and profit shifting. Paris: OECD Publ.; 2013. 91 p. DOI: 10.1787/9789264192744-en

8. Haufler A., Mardan M., Schindler D. An economic rationale for controlled-foreign-corporation rules. In: Annual conference: Evidence-based economic policy. Hamburg: Association for Social Policy; 2014. URL: https://www.econstor.eu/bitstream/10419/100405/1/ VfS_2014_pid_973.pdf

9. Grubert H. The tax burden on cross-border investment: Company strategies and country responses. CESIFO Working Paper. 2003;(964). URL: https://www.ifo.de/DocDL/cesifo_wp964.pdf

10. Whalley J. Puzzles over international taxation of cross border flows of capital income. NBER Working Paper. 2001;(8662). URL: https://www.nber.org/papers/ w8662.pdf

11. Vishnevskii V., Grechishkin A. Effects of taxation scheme upon capital migration. Mirovaya ekonomika i mezhdunarodnye otnosheniya = World Economy and International Relations. 2002;(12):18-24. (In Russ.).

12. Sutyrin S.F., Pogorletskii A.I. Taxes and tax planning in the global economy. St. Petersburg: V.A. Mikhailov Publ.; Polius; 1998. 577 p. (In Russ.).

13. Harry Grubert, in memoriam. National Tax Association. 2013. URL: https://www.ntanet.org/ fpstory/2017/08/harry-grubert-in-memoriam/ (accessed on 31.01.2019).

14. Jorgenson D. Capital theory and investment behaviour. The American Economic Review. 1963;53(2):247-259.

15. OECD Transfer pricing guidelines for multinational enterprises and tax administration. Paris: OECD Publ.; 2010. 371 p. URL: https://read. oecd-ilibrary.org/taxation/oecd-transfer-pricingguidelines-for-multinational-enterprises-and-taxadministrations-2010_tpg-2010-en\#page1

16. Transfer pricing: Secondary adjustments. HMRC consultation. London: Ernst \& Young LLP; 2016; 2 p.

17. Paying taxes 2016. London: PWC; World Bank Group; 2015. 144 p. URL: https://www.pwc.com/gx/ en/paying-taxes-2016/paying-taxes-2016.pdf

18. Lipatova I.V., Polezharova L.V., International tax planning methodology and best practices of Russian economy deoffshorization. Asian Social Science. 2015;11(19):316-328. DOI: 10.5539/ass.v11n19p316 
19. Vernon R. In the hurricane's eye: The troubled prospects of multinational enterprises. Cambridge, MA, London: Harvard University Press; 1998. 288 p.

20. Krasnov I. Transfer pricing and international taxation practices of multinational corporations. Upravlenie ekonomicheskimi sistemami: elektronnyi nauchnyi zhurnal = Management of Economic Systems: Scientific Electronic Journal. 2013;(5):11. URL: http://www. uecs.ru/otraslevaya-ekonomika/item/2134-2013-0513-06-54-04 (In Russ.).

21. Célestin L.C. The formulary approach to the taxation of transnational corporation: A realistic alternative? PhD thesis. Synopsis. 2000. URL: https://ses.library.usyd.edu.au/bitstream/ handle/2123/846/adt-NU20020917.13313801front. pdf? sequence $=1$ \&isAllowed $=y$

22. Bhat G. Transfer pricing, tax havens and global governance. Deutsches Institut für Entwicklungspolitik. Discussion Paper. 2009;(7). URL: https://www.files.ethz.ch/isn/102933/2009-07e. pdf

23. Commission proposes major corporate tax reform for the EU. Press release. Strasbourg: European Commission; Oct. 25, 2016. URL: https://ec.europa.eu/commission/presscorner/detail/en/IP_16_3471 